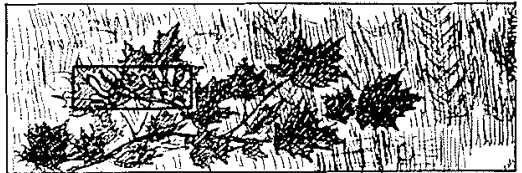

\title{
Vocational Guidance
}

\section{Literature Discussed}

In the middle of July a letter was received by a number of educational institutions and professional and forestry associations of Canada, as well as the Canadian Council of Professional Engineers and the Bio-physical sciences program of the Public Service Commission.

The subject of the letter was "Canadian occupations - vocational guidance literature". The letter was issued by the Occupational Analysis Unit of the Department of Manpower and Immigration and it stated in part that the unit is currently producing the following publications:

Occupational Briefs and Entry Requirements for "Forester", "Forest Engineer".

Although it was pointed out that the enclosed were unedited, preliminary drafts of the papers, a scheduled date of August 28, 1968 . was named as the printing date for the literature. Dean J. W. B. Sisam of the Faculty of Forestry, University of Toronto, as well as a number of other professional foresters interested in career guidance, were somewhat disturbed. Dean Sisam's letter follows.

Mr. W. Coe,

Head,

Occupational Analysis Unit,

Department of Manpower and Immigration, Ottawa, Ontario.

Dear Mr. Coe:

With reference to my telegram which was sent to you in the latter part of July, I am writing to confirm my strong objection to the proposal by your Unit to issue two Occupational Briefs, one dealing with Forest Engineering and the other with Forestry. As I have suggested, this implies that there are two separate professional groups involved with the management and operation of our forest resources - a concept that can only be detrimental to the profession of forestry which over the past sixty years has been in the process of establishing through training and experience the personnel necessary to deal comprehensively with this aspect of Canada's economic development.

Before going into further detail on this matter, I should point out that in your distribution list for these briefs there was a serious omission - the Canadian Institute of Forestry at Macdonald College, P.Q. Also, the address of the Ontario Professional Foresters Association is: Suite 34, 31 Yonge St. N., Richmond Hill, Ontario.

Turning now to the Brief on Forest Engineering, I would suggest that a good many of the items listed under "Nature of Work" can be undertaken by foresters and otherwise by Civil or Design (Mechanical or Industrial) Engineers where the nature and complexity of the problem is such as to require the assistance of a professional in this field. In fact, the list of activities as shown does not suggest the need for a new category of engineer, but rather a close co-operation between foresters and engineers in the established areas of competence. 
But quite apart from this is the need to recognize that the harvesting operation must be an integral part of the forester's responsibility, and therefore graduates in forestry, who are to be directly involved in harvesting, must be properly qualified to undertake the surveying, analytical work, programming, planning, and operations associated therewith. This must be increasingly so as forest management intensifies in relation to future productivity and the requirements of multiple use of the forest to furnish goods and services in demand by industry and society. The survey, planning, and evaluation of forestry problems associated with these trends must be the responsibility of the Forester, and where the solution of his problems require the design of certain relatively sophisticated types of equipment, undoubtedly he will call on the civil or mechanical engineer to assist him, but this does not make the latter a Forest Engineer.

Perhaps part of the apparent confusion relates to the practice, common during the early stages of forestry in this country, of using the terms "Forester" and "Forest Engineer" interchangeably without, however, implying professional engineering qualification by the latter. This practice probably originated in part from European terminology. Indeed. from the time the Faculty of Forestry was established at the University of Toronto in 1907 with Dr. Fernow, a German forester, in charge, there was a postgraduate degree offered under the title "Forest Engineer." Its award did not require any engineering quaiification, and in order to avoid confusion it was withdrawn in 1953.

Also, until 1950 the national professional foresters association in Canada was known as the Canadian Society of Forest Engineers; this was changed in 1950 to the Canadian Institute of Forestry, in part to avoid misrepresentation. In Quebec, the provincial foresters, in order to gain recognition early became associated with the civil engineers, and in 1923 the Corporation des Ingénieurs Forestiers de la Province de Québec was formed. However, I shouid say that the use of the term "forest engineer" in that province is synonymous with the use of the term "forester" in other parts of the country. In this province, the Ontario Professional Foresters Association was formed in 1957, and in preparation for that, every effort was made to ensure that there would be no over-lap or conflict with the Association of Professional Engineers.

I have gone into this in detail simply to emphasize that (i) Forestry and Engineering are two separate professions, (ii) based on history rather than professional qualification, there has been an interchange of the terms "Forester" and "Forest Engineer," and (iii) with the exception of Quebec, this is becoming less possible as the professional identification and requirements of each acquire greater significance.

I feel sure that the linking of Forestry with the names of other professions and disciplines in relation to either academic or professional qualification can only do harm to Forestry in the eyes of the general public, and in fact tends to create a dual misrepresentation. Some time ago at the University of Toronto a degree course was offered under the title "Business and Engineering." This proved to be neither one thing nor the other and eventually was withdrawn.

In view of what has been said above, I would recommend that only one Occupation Brief be issued and that under the title Forester, but reference be made to the use of the term Forest Engineer (Ingénieur Forestier) with particular reference to Quebec.

Yours sincerely,

J. W. B. Sisam, Dean

\section{Endorsation Request}

To: Dean J. W. B. Sisam, Faculty of Forestry, Uni. versity of Toronto

Ontario Forestry Association

Ontario Professional Foresters Association

Canadian Institute of Forestry

Canadian Lumbermen's Association

Canadian Pulp and Paper Association

Canadian Forestry Association

Gentlemen:

Recently a group called the Algonquin Wildlands League has campaigned in the press with the avowed intent of forcing the logging industry out of Algonquin Park. It has criticized the Department of Lands and Forests for allowing the construction of roads in the Park.

It is the intent of this letter to request endorsation for the following principles:

1. To achieve the maximum benefit for the people of Ontario, Algonquin Park must continue to be managed on the basis of sustained yield and multiple use.

2. A feature of proper forest management is the removal of mature timber. Areas of overmature timber invite attack by fire, insects and disease. Overmature trees occupy space that should be used for younger healthier trees.

3. A basic necessity for proper forest management is a network of roads. Roads are required, not only for the harvesting of timber, but for efficient control of fire, insects and disease; compilation of research and inventory data.

Before endorsing these principles, you should be made aware that such endorsation will probably appear in press releases. It is felt in some quarters that the Department of Lands and Forests, the logging industry and the forestry profession should reply to some of the irresponsible attacks against them by such extremists as the Algonquin Wildlands League.

$$
\begin{aligned}
& \text { Yours truly, } \\
& \text { R. B. Loughlan } \\
& \text { Manager } \\
& \text { Ontario Forest Industries } \\
& \text { Association }
\end{aligned}
$$




\section{March “Rod \& Gun” Editorial}

Mr. Willsie's editorial in the March, 1968, issue of "Rod \& Gun in Canada" contains a number of generalizations regarding the relationship between logging operations for pulpwood and the welfare of populations of deer inhabiting the areas subject to logging. Like most sweeping generalizations, some of these are less than accurate, especially when applied to any particular set of circumstances. Meaningful comment on all of them would require much more space than you are likely to allow me.

Mr. Willsie's central theme is that pulpwood logging operations reduce the carrying capacity of an area for deer. While this may not be universally true, it would constitute a reasonably accurate reflection of circumstances in one area with which $\mathrm{Mr}$. Willsie is undoubtedly quite familiar - the prime deer area to the north and west of Montreal which has recently suffered serious population declines. A study of the problem area has recently been completed and reported upon by Dr. D. H. Pimlott and associates. Their report places considerable emphasis on the urgency of modifying cutting practices in those portions of the area which serve as winter range for deer. Past and current cutting methods have, in general, reduced coniferous crown cover below the minimum required to shelter deer from deep snow and cold winds. Some of the traditional wintering areas in Argenteuil, Terrebonne, Papineau and Labelle counties have been abandoned by deer following recent pulpwood operations. Abandonment, in these cases, probably involved drastic shrinkage of the herd through excessive losses during recent severe winters following removal of vital coniferous shalter.

Among other misleading generalizations must be included the one repeated so often by foresters to the effect that cutting operations are good for game. They may be good or they may be bad, depending upon the circumstances. The best compromises are worked out by game manager and timber manager participating in joint planning of the operation, as is now being done in so many jurisdictions.

R. C. Passmore,

Executive Director,

Canadian Wildlife Federation, Ottawa.

\section{UNB Forestry Association}

As a result of our Forestry Association elections, a new executive has been chosen for the academic year 1968-69. I have been elected as the new President of the Association.

Due to the closeness of our organizations over the years, it had been my intention to write sooner, but various circumstances prevented me from doing so.

I am hoping that we will be corresponding frequently throughout the coming year regarding C.I.F. activities, so that I can pass this information on to our members.

I would also be grateful if you could send information on student membership, so that in the fall I will be able to clearly encourage C.I.F. membership.

Will we still be able to place an article in the new Forestry Chronicle during the coming year? I have been quite impressed with the new Chronicle and am looking forward to bigger and better things.

Joseph T. O'Leary.

President, U.N.B.,

Forestry Association.

\title{
R. E. KEEN \& ASSOCIATES
}

\section{Consulting Foresters}

3236 The Credit Woodlands, - Cooksville, Ontario

Tel.: (Area Code 416) 279-9405

\section{Would you believe}

\section{a good supply of SWEDISH STEEL TIMBER CALIPERS?}

\author{
Almost as rare as a \\ pearl in an oyster... \\ but Mike Sauze at \\ Canadian Forestry \\ Equipment Co. carries \\ a full stock.
}

Twelve- to 30 -inch

sizes, priced from

$\$ 14.00 \ldots$ for immediate

shipment.

Mike Sauze is

Canada's

equipment

specialist

stocking,

cataloguing and

shipping by mail

order all technical

equipment, forestry

supplies and instru-

ments required by

Canadian foresters.

Request a catalogue with your order for Swedish steel calipers today.
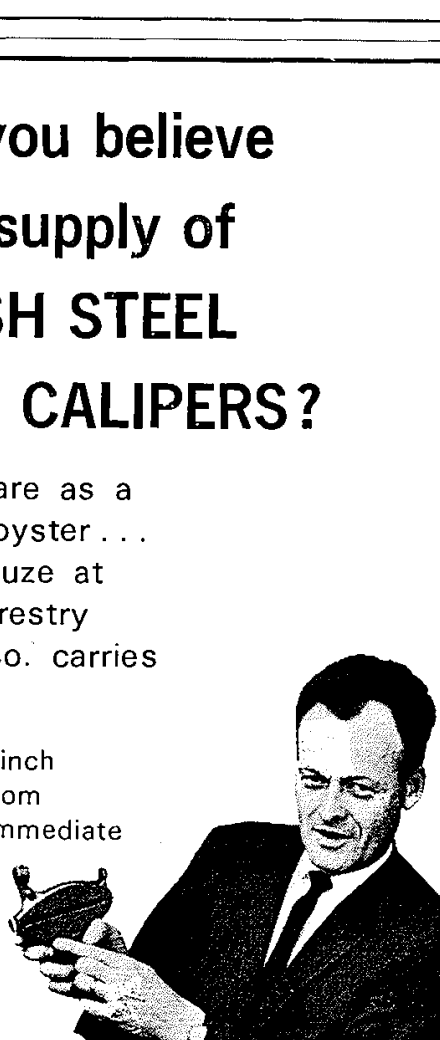


\section{For the Sake of Argument}

\section{Conversion Surplus: Help or Hindrance?}

For many foresters much of the jargon used by forest mensurationists and economists is unwanted, and constitutes an obstacle to a clear understanding of the issues discussed (some who try to follow the literature would regard that as an unamusing understatement). One example of confusing terminology is found in connection with the evaluation of timber, where we find references to "stumpage", "conversion surplus" and "conversion return" among other terms. One is tempted to ignore the differences that writers ascribe to these terms, but the literature in which they are used touches on extremely important econom:c issues in forestry. This author has therefore concluded (somewhat reluctantly) that given the present state of confusion it would be useful to attempt yet another clarification of the basic differences among some of the important concepts of wood evaluation. Hopefully we will find that we can do better without some of the less palatable jargon.

In a recent article in this journal, William Duerr and Sam Guttenberg (1968) attempted to clarify the concept of "conversion surplus", a term which they introduced two decades ago (Guttenberg and Duerr, 1949). Their clarification was apparently inspired by a footnote reference to conversion surplus in an article by this writer (Pearse 1967) last year. Duerr and Guttenberg claimed that my criticism of their conversion surplus as a measure of timber values involved a misunderstanding.

Unfortunately, a response to Duerr and Guttenberg necessitates interpretation of conversion surplus as they themselves intended it, since they introduced the concept to the literature. Perhaps the best approach is to contrast Duerr and Guttenberk's idea of conversion return with that of stumpage as both are applied to the value of standing timber.

Conversion surplus ". . . is a measure of the excess, if any, of marginal revenue over marginal cost for a given unit of production." (Duerr and Guttenberg, $1968, p .25)$. This appears to mean the difference between the end value of products that can be produced from a firm's unit of input (e.g. a log or tree) and the additional costs the firm would incur in processing it. Duerr and Guttenberg's own definition however, is confusing because of their use of two terms in a way that differs importantly from their meaning in conventional economic literature. First, with the exception of the sentence quoted above, and in one or two other places in their article, they consistently substitute the term "variable cost" for "marginal cost" and imply that they mean the same thing (in one case they write ". . . it is variable - i.e. marginal" (p. 25). But variable cost is not the same thing as marginal cost (except in the unlikely case of linear variable costs, which they do not postulate, and at that specific level of output where marginal cost just coincides with minimum variable cost). Variable cost normally means the average non-fixed costs of production, while marginal cost refers to the change in total costs resulting from a marginal change in output. The other confusion arises over their term "unit of production", which in economic literature refers to a unit of output, while Duerr and Guttenberg apply it to a unit of input. Nevertheless the rest of their article makes it clear that they mean to define conversion surplus as the value to the firm of the final products it can produce from a unit of input minus the additional costs it would incur in producing them. In conventional economic terms, this is the marginal net revenue to be gained from processing the unit of input, and is the answer to Duerr and Guttenberg's ". . . specific question: What difference will it make financially if the producer converts these goods (inputs) into end products?" (p. 24).

Stumpage, as everyone appears to agree, refers to the value of trees standing in the woods. In a competitive market situation this is the value of the timber harvested and delivered to a market centre or mill minus the costs of logging and transport. It is thus the maximum amount a competitive bidder would be prepared to pay for the timber. The question we want to address, then, is the difference between this and Duerr and Guttenberg's conversion surplus.

Duerr and Guttenberg maintain that conversion surplus is typically larger than stumpage because the latter is net not only of the marginal costs of conversion but also of an "... arbitrary (sic) fraction of the firms prospective fixed costs . . ." and "... an arbitrary fraction of an allowance for the firm's 'profit' and 'risk'..." (page 26). Now apart from the "arbitrary" element here, which would alarm most economists, the problem reduces to whether fixed costs and an allowance for profit and risk constitute new and additional deductions from conversion surplus to yield stumpage value.

Before proceeding with this question, three points should be made. First, government agencies and companies have institutionalized various definitions and procedures for calculating these terms which are of no basic theoretical interest here. We are interested in principles for correctly calculating the real economic value of timber. Second, any writer or writers may define these terms as he chooses: we are interested here in the appropriateness of definitions for specific economic purposes in decision-making. Third, we observe that Duerr and Guttenberg themselves concede ( $p$. 25) that conversion surplus and stumpage value are identical from the point of view of the timber owner selling stumpage where he incurs no expenses in making a sale.

If we consider a parcel of standing timber and a competitive market situation (as Duerr and Guttenberg implicitly do), what is the difference between what the owner can gain from a sale (stumpage) and the value of the raw material to a harvesting firm (conversion surplus)? More specifically, does the value of this timber to the firm (conversion surplus) exceed its willingness to pay for it (stumpage) to the extent of allowances for fixed costs, profit and risk? 
Surely not. Fixed costs by definition, will be incurred by the firm anyway. They are relevant only in determining the long-run profitability of the enterprise (whether it will stay in business in the long run) but not in any decision relating to the desirability of an expansion or contraction of operations and hence of its ability to pay for a little more input. The profit maximizing firm will always expand output as long as the extra or marginal cost of doing so is less than the marginal revenue that can be expected from doing so. Thus it is prepared to pay in stumpage any amount up to the difference between marginal operational costs and the marginal value of the output - which is what Duerr and Guttenberg define as conversion surplus.

Profit and risk involves a more difficult consideration. With respect to profits, it is difficult to say whether the appropriate base for a profit calculation is the value of output or of investment (Duerr and Guttenberg ascribe their "arbitrary" profit allowance to the input - the tree (p. 26) which raises the question about profit allowances to all other inputs. Nevertheless, if we adopt the usual concept of profits for a competitive firm, we can assert that normal profit - the return to the entrepreneur, necessary to keep him in business in the long run is not affected by an expansion or contraction in short-run operations. On the other hand, if profit is conceived as a rate of return on invested capital, this too is unaffected by short-run adjustments in output because, by definition, the capital stock will not change.

Finally, there is no economic justification that this author is aware of that suggests risk leads to a difference between the values of a unit of input to a firm and the firm's willingness to pay for it. In the first place, risk is properly regarded as a cost of operation, and in the second, it is generally agreed that a larger operation (i.e. with the extra production) is less risky than a smaller operation. We conclude, then, that the alleged distinction between a firm's evaluation of an input (conversion return) and its willingness to pay for it (stumpage) is unreal.

Duerr and Guttenberg's distinction would be slightly more appropriate only if conversion return applied to the evaluation of marginal inputs while stumpage applied to blocks of timber which both buyer and seller were forced to regard as the entire input for the life of a given firm. Then, indeed, fixed costs would have to be considered in the latter but not in the former. But Duerr and Guttenberg apply both concepts to the same (marginal) example ( $p$. 26).

This present discussion was touched off by my assertion (Pearse, 1967, footnote 2) that

A normal profit to the logger and an allowance for risk must be considered part of the real cost of logging. (For administrative purposes, stumpage is sometimes defined gross of these items). William A. Duerr, among others, argues that the appropriate measure for evaluation is not stumpage but "conversion surplus", which is the value of the end product of the entrepreneur's production process (e.g. lumber or pulp) minus all costs of manufacture (Duerr 1960). This is incorrect, because it involves attributing to the timber profits that should properly be attributed to factors of production in the utilization processes.

This argument, it seems to me, remains correct (although it might have been a less ambiguous interpretation of Duerr had the word "marginal" been inserted before ". . . costs of manufacture ..."). Surely the profitability of an entire vertically-integrated utilization complex cannot be attributed to the wood input. Moreover, firms are seldom so insulated from markets that they lack evaluations of intermediate products, or opportunities to buy and sell intermediate products.

Whether or not a firm's utilization plant is integrated with a woods operation and completely insulated from intermediate product markets, its criterion for determining the intensive margin of utilization will rest on equating the marginal cost of a unit of input with the marginal revenue to be gained from using it. Where a log market exists, however, the integrated firm faces two alternative marginal costs - that of purchasing the wood, and that of logging it from its own operations. A profit-maximizing firm will prefer to draw on whichever source is cheapest, but will draw on either as long as the marginal cost is less than the marginal revenue from doing so.

It is possible, however, to conceive of certain market imperfections (notably monopsony) in which the firm would be unwilling to pay (and the owner would be unable to get) a stumpage value equal to the real net worth of the timber. These, however, are not postulated by Duerr and Guttenberg, and will not be pursued here.

In short, the concept of conversion surplus as used by Duerr and Guttenberg not only threatens to impede a correct understanding of the economic principles of evaluation but will inevitably be confused with "conversion return", which is a well established concept in stumpage appraisal and which differs from Duerr and Guttenberg's conversion surplus only insofar as it includes fixed costs (Duerr, 1960, p. 383). The alleged value of conversion surplus as a guide to timber evaluation appears to be based on a faulty interpretation of economic theory, and is one which could be dispensed with to advantage. If we wish to refer to the marginal net value of an input it would be preferable to use these unequivocal terms themselves.

\section{REFERENCES}

Duerr, W. A. 1960. Fundamentals of Forestry Economics. McGraw-Hill Book Company Inc., New York. 579 pp.

Duerr, W. A. and Sam Guttenberg. 1968. Conversion Surplus as a Measure of Value. For. Chron., 44, 24-27.

Guttenberg, Sam and W. A. Duerr. 1949. A Guide to Profitable Tree Utilization. Southern Forest Experiment Station Occasional Paper 114, New Orleans.

Pearse, P. H. 1967. The Optimum Forest Rotation. For. Chron. 43, pp. 178-195.

Peter H. Pearse 